\title{
CONTRACT IN EUROPEAN UNION PUBLIC PROCUREMENT LAW
}

\begin{tabular}{llll}
\hline A. INTRODUCTION & 1.01 & F. TERM OF VALIDITY OF A CONTRACT & 1.45 \\
B. CONTRACT FOR PECUNIARY INTEREST & 1.11 & G. TERMINATION OF A CONTRACT & 1.50 \\
C. FORM OF EXECUTION OF A CONTRACT & 1.17 & H. FRAMEWORK AGREEMENT & 1.68 \\
D. PARTIES TO A CONTRACT & 1.20 & I. CONCLUSIONS & 1.74 \\
E. SUBJECT MATTER OF A CONTRACT & 1.39 & &
\end{tabular}

\section{A. INTRODUCTION}

1.01 According to the wording of Article 1(1) of Directive 2014/24/EU, the directive establishes rules on the procedures for procurement by contracting authorities with respect to public contracts with a value estimated to be equal to or above the thresholds laid down in Article 4 thereof. In fact, the scope of Directive 2014/24/EU goes far beyond rules on the procedures for procurement. In particular, Title II of the directive, called 'Rules on public contracts', addresses not only procedures aimed at selecting the most advantageous tender, but also contract performance, including the 'modification of contracts during their term', as envisaged by Article 72.

1.02 Interestingly, Directive 2014/24/EU does not provide an express definition of 'contract', though this does not mean that the concept is not there. First of all, Directive 2014/24/EU defines 'procurement' as 'the acquisition by means of a public contract of works, supplies or services by one or more contracting authorities from economic operators chosen by those contracting authorities, whether or not the works, supplies or services are intended for a public purpose'. ${ }^{1}$ According to Article 2(1)(5) of Directive 2014/24/EU, 'public contracts' mean 'contracts for pecuniary interest concluded in writing between one or more economic operators and one or more contracting authorities, and having as their object the execution of works, the supply of products or the provision of services'. ${ }^{2}$ As aptly noted by C. Risvig Hansen, a 'public contract'

1 Art 1(2).

2 It is unclear why there are three separate, though related, notions in Directive 2014/24/EU, namely a contract, a public contract and procurement. Indeed, this distinction has caused some problems in certain non-English language versions. See also Roberto Caranta, 'Mapping the margins of EU public contracts law: Covered, mixed, excluded and special contracts' in Francois Lichère, Roberto Caranta, Steen Treumer, Modernising Public Procurement: The New Directive (Djøf 2014), p 70. It seems that the EU lawmakers might have made an attempt to combine the definitions of 'public contract' and 'procurement', for instance, by stating that public contracts mean 'contracts ... having as their object the question of works, the supply of products or the provision of services'. 
is first and foremost a 'contract'. ${ }^{3}$ Indeed, Recital 34 of Directive 2014/24/EU emphasises the significance of the public contract being a contract:

[c] ertain cases exist where a legal entity acts, under the relevant provisions of national law, as an instrument or technical service to determined contracting authorities, is obliged to carry out orders given to it by those contracting authorities and has no influence on the remuneration for its performance. In view of its non-contractual nature, such a purely administrative relationship should not fall within the scope of public procurement procedures. ${ }^{4}$

The notion of a contract is a matter of the European Union law. ${ }^{5}$ This means that, in order to 1.03 determine the content and scope of this notion, its qualification in national law is irrelevant for establishing whether it is covered by the EU public procurement laws. ${ }^{6}$

Under Directive 2014/24/EU, in order for a public contract to be present, it is necessary for 1.04 such a contract to be:

- for pecuniary interest;

- concluded in writing;

- between one or more economic operators and one or more contracting authorities;

- and its subject matter must be the execution of works, the supply of products or the provision of services.

The Court has already held that since a contract is for pecuniary interest, the contractor assumes a direct or indirect obligation to carry out the works which are the subject of the contract and that that obligation be legally enforceable in accordance with the procedural rules laid down by national law. ${ }^{7}$ In this context it was submitted that the concept of 'public contract'

3 See Carina Risvig Hansen, 'The concept of a "public contract” within the meaning of the Public Procurement Directive' (2016) Procurement Law Journal No. 3, p 183.

4 This view was formulated by the Court well before Directive 2014/24/EU entered into force. See the judgment of the Court of 18 December 2007 in Case C-220/06 Asociación Profesional de Empresas de Reparto y Manipulado de Correspondencia, ECLI:EU:C:2007:815, in which the Court held as follows (para 54):

[i]f the agreement between [the economic operator] and the [contracting authority] were in actual fact a unilateral administrative measure solely creating obligations for [the economic operator], and as such a measure departing significantly from the normal conditions of a commercial offer made by that company ... it would have to be held that there is no contract and that, consequently, [the directive] could not apply.

See, however, the definition of a 'public service contract' given in Regulation (EC) No 1370/2007 of the European Parliament and of the Council of 23 October 2007 on public passenger transport services by rail and by road and repealing Council Regulations (EEC) Nos 1191/69 and 1107/70, concerning procurement leading to the execution of a public service contract in the public passenger transport. Under Article 2(i) of this Regulation, such public service contract means:

[o]ne or more legally binding acts confirming the agreement between a competent authority and a public service operator to entrust to that public service operator the management and operation of public passenger transport services subject to public service obligations; depending on the law of the Member State, the contract may also consist of a decision adopted by the competent authority, taking the form of an individual legislative or regulatory act, or containing conditions under which the competent authority itself provides the services or entrusts the provision of such services to an internal operator. Judgment of the Court of 20 October 2005 in Case C-264/03 Commission v France, ECLI:EU:C:2005:620, para 36; judgment of the Court of 18 January 2007 in Case C-220/05 Auroux, ECLI:EU:C:2007:31, para 40, and judgment of 18 July 2007 in Case C-382/05 Commission v Italy, ECLI:EU:C:2007:445, para 30.

6 Sue Arrowsmith, The Law of Public and Utilities Procurement: Regulation in the EU and UK, Volume I (Sweet \& Maxwell 2014), p 388; Christopher Bovis, The Law of EU Public Procurement (Oxford University Press 2016), p 371.

7 Judgment of the Court of 25 March 2010 in Case C-451/08 Helmut Müller, ECLI:EU:C:2010:168, para 63. 
also requires a 'direct economic benefit' brought by the economic operator to the contracting authority. ${ }^{8}$ Indeed, in its judgment in Case C-451/08, the CJEU ruled that the said concept: 'requires that the works which are the subject of the contract be carried out for the contracting authority's immediate economic benefit; it is not, however, necessary that the service should take the form of the acquisition of a material or physical object'. ${ }^{9}$

1.06 However, the CJEU's judgment was not given in abstracto, but addressed a specific reference for a preliminary ruling from the Oberlandesgericht Düsseldorf, which asked the Court, in the context of the German provision, whether the concept of 'public works contracts', within the meaning of Article 1(2)(b) of Directive 2004/18, requires that the works be physically carried out for the contracting authority in its direct economic interest. One should conclude that the direct economic benefit is just an element of pecuniary interest and not one more part of the definition of a public contract. This was emphasised by the Court in Case C-51/15:

[o]nly a contract concluded for pecuniary interest may constitute a public contract coming within the scope of Directive 2004/18, the pecuniary nature of the contract meaning that the contracting authority which has concluded a public contract receives a service which must be of direct economic benefit to that contracting authority..$^{10}$

1.07 From the point of view of this book, it is important to discuss the concept of a (public) contract for at least two reasons.

1.08 First, 'contract modification' assumes that a contract is in place. In other words, only a contract in the meaning of the term under EU public procurement law may be modified in accordance with the rules set out in Directive 2014/24/EU or the general rules of public procurement law in the event that public procurement directives do not apply. When a given contract is deemed not to fulfil the criteria arising from EU law (for instance, it is not concluded for pecuniary interest), it is not necessary to determine whether a modification of such contract is compliant with European Union public procurement law.

1.09 Second, the modification of a contract usually takes the form of an amendment agreement (an annex to the existing contract), which is a contract in itself. Thus, considerations regarding a contract include a contract modification.

1.10 Taking this into account, the following conditions will be examined first: the pecuniary interest, the parties to a contract and the subject matter thereof. Then the term of validity and the termination of a contract in EU public procurement law will be discussed. Finally, the concept of a framework agreement will be considered. Whenever appropriate, reference will be made to the context of contract modification.

8 See Marek Szydło, Prawna koncepcja zamówienia publicznego (C.H. Beck 2014), p 162.

9 Judgment of the Court of 25 March 2010 in Case C-451/08 Helmut Müller, ECLI:EU:C:2010:168, para 54.

10 Judgment of the Court of 21 December 2016 in Case C-51/15 Remondis, ECLI:EU:C:2016:985, para 43. 


\section{B. CONTRACT FOR PECUNIARY INTEREST}

Article 2(1)(5) of Directive 2014/24/EU clearly provides that a contract must be concluded for pecuniary interest. However, no definition of the term 'pecuniary interest' is anywhere to be found. Neither the literal wording of Article 2(1)(5) of Directive 2014/24/EU, nor a systemic interpretation of Directive 2014/24/EU is of much help. ${ }^{11}$ The issue has been the subject of much analysis in the CJEU case law and by the Advocates General, further to which it is safe to assume that the term 'pecuniary interest' should be interpreted broadly - with regard to the objectives of the public procurement directives of opening up the markets in the area of public works, services and supplies, as well as contributing towards the attainment of freedom of establishment and the freedom to provide services in that regard. ${ }^{12}$

It is clear from the usual legal meaning of 'for pecuniary interest' that the term designates a contract by which each of the parties undertakes to provide the other with some form of consideration. ${ }^{13}$ Such reciprocity of the contractual relationship, ${ }^{14}$ or in other words the synallagmatic nature of the contract, ${ }^{15}$ is necessary for the requirement of a tendering procedure to apply, making it an essential element of a public contract. At the same time, it is submitted that it is the pecuniary interest that, from a practical point of view, ensures the proper level of competition and attracts economic operators tendering for public contracts. ${ }^{16}$ It does not necessarily mean that the consideration needs to consist of the payment of a sum of money by the contracting authority. ${ }^{17}$ As noted by Advocate General Léger, economic operators are motivated by the prospect of obtaining some economic benefit from contracts. ${ }^{18}$

Consequently, works, supplies or services may be compensated for by any other forms of consideration, such as reimbursement of the expenditure incurred, either directly or indirectly, ${ }^{19}$

11 Opinion of Advocate General Bobek delivered on 28 May 2020 in Case C-367/19 Tax-Fin-Lex, ECLI:EU:C:2020: 400 , para 40.

12 Opinion of Advocate General Kokott delivered on 15 June 2006 in Case C-220/05 Auroux, ECLI:EU:C:2006:410, para 57.

13 See to that effect judgment of the Court of 18 October 2018 in Case C-606/17 IBA Molecular Italy, ECLI:EU:C:2018: 843 , para 28.

14 Opinion of Advocate General Trstenjak delivered on 23 May 2012 in Case C-159/11 Ordine degli Ingegneri della Provincia di Lecceand Others, ECLI:EU:C:2012:303, para 30.

15 Judgment of the Court of 10 September 2020, Case C-367/19 Tax-Fin-Lex, ECLI:EU:C:2020:685, para 25.

16 See Szydło (n 8), p 183.

17 See, however, judgment of the Court of 13 July 2018 in Case C-701/15 Malpensa Logistica Europa, ECLI:EU:C:2017: 545 , para 29.

18 Opinion of Advocate General Léger delivered on 7 December 2000 in Case C-399/98 Ordine degli Architettiand and Others, ECLI:EU:C:2000:671, para 94.

19 Judgment of the Court of 11 December 2014, Case C-113/13 Azienda sanitaria locale n. 5 'Spezzino'and Others, ECLI: EU:C:2014:2440, para 37. The Court agreed with Advocate General Wahl, who defined in its opinion 'direct costs' as marginal costs, and 'indirect costs' as a part of fixed costs, calculated in proportion to the share that services entrusted have in the overall activity of the organisation. See opinion of Advocate General Wahl delivered on 30 April 2014 in Case C-113/13 Azienda sanitaria locale n. 5 'Spezzino' and Others, ECLI:EU:C:2014:291, para 27. 
in providing the agreed work, supply or service, ${ }^{20}$ forgiving the economic operator's debt ${ }^{21}$ or cancelling a tax obligation. ${ }^{22}$

1.14 In turn, a contract under which a contracting authority is not legally obliged to provide any consideration does not fall within the concept of a 'contract for pecuniary interest' within the meaning of Article 2(1)(5) of Directive 2014/24/EU. This was clearly confirmed by the Court in Case C-367/19, in which one of the tenderers proposed a price of EUR 0.00. In the view of the Court:

$[t]$ he fact $[\ldots]$ that the award of the contract could be of economic value to the tenderer in that it would open up access to a new market or enable the tenderer to receive references, is too uncertain and is therefore insufficient to characterise the contract as a 'contract for pecuniary interest'. ${ }^{23}$

1.15 However, the fact that a given contract cannot generate 'substantial net revenues' for an economic operator does not seem to be a problem in the context of 'pecuniary interest'. In other words, consideration for the economic operator does not have to be equivalent. In Case C-388/12, the Court explained it as follows:

[i]n the context of an economic strategy to extend part of its activities to another Member State, an undertaking may take the tactical decision to seek the award in that State of a concession despite the fact that that concession is incapable as such of generating sufficient profit, since that opportunity could nevertheless enable the undertaking to establish itself on the market of that State and to make itself known there with a view to preparing its future expansion. ${ }^{24}$

1.16 The issue of pecuniary interest is referred to, though not directly, in the provisions of Directive 2014/24/EU concerning contract modification. Article 72(1)(a), when speaking about review clauses, mentions the 'monetary value' of modifications, and then provides that those clauses may include 'price revision clauses'. In turn, the first sentence of the second paragraph of Article 72(1)(b), concerning the modification of a contract for additional works, supplies or services, and Article 72(1)(c)(iii), concerning modifications caused by unforeseeable circumstances, set as a limit on possible modifications - an 'increase in price' that cannot exceed ' $50 \%$ of the original contract' (where several successive modifications are made, that limitation applies to the value of each modification). Finally, Article 72(2), regarding de minimis modifications, makes a reference to the original contract 'value', as well as to the modification value. Thus, those provisions apply to contracts where there is no doubt that they include consideration to be given to the economic operator, and thus, are concluded for a pecuniary interest.

Judgment of the Court of 19 December 2012 in Case C-159/11 Ordine degli Ingegneri della Provincia di Lecce and Others, ECLI:EU:C:2012:817, para 29.

21 Judgment of the Court of 12 July 2001 in Case C-399/98 Ordine degli Architettiand and Others, ECLI:EU:C:2001:401, para 84. See also Arrowsmith (n 6), pp 394-395, in the context of cases pending before the UK courts.

22 Ibid., p 396.

23 Judgment of the Court of 10 September 2020 in Case C-367/19 Tax-Fin-Lex, ECLI:EU:C:2020:685, para 28. See also the opinion of Advocate General Bobek delivered on 28 May 2020 in Case C-367/19 Tax-Fin-Lex, ECLI:EU:C:2020: 400, paras 63-65.

24 Judgment of the Court of 14 November 2013 in Case C-388/12 Comune di Ancona, ECLI:EU:C:2013:734, para 51. 


\section{FORM OF EXECUTION OF A CONTRACT}

A public contract must be concluded in writing. According to Article 2(1)(18) of Directive 2014/24/EU, 'in writing' means: 'any expression consisting of words or figures which can be read, reproduced and subsequently communicated, including information transmitted and stored by electronic means', where 'electronic means' is understood as: 'electronic equipment for processing (including digital compression) and storing data which is transmitted, conveyed and received by wire, by radio, by optical means or by other electromagnetic means' ${ }^{25}$

Sue Arrowsmith has expressed a doubt, though without giving any rationale, as to whether it is reasonable to limit contracts to 'contracts concluded in writing' only. ${ }^{26}$ It seems, however, that this limitation makes sense, in particular from the point of view of the principle of legal certainty. It is hard to imagine how contracts for public procurements could function in practice if not concluded in writing, especially in the case of large and long-term infrastructural projects. Written form certainly ensures an adequate transparency level to enable the verification of equal treatment principle. $^{27}$

In the context of the form of concluding a contract, it is also important to pay attention to the form of contract modification. Usually, this is a document expressly amending the existing provisions of the contract, for instance in the form of an annex. However, no provision of Directive 2014/24/EU actually requires a contract modification to take any specific form (such as an annex). It may also happen that a modification will be an effect of a settlement between the parties, whereby, for instance, the economic operator will receive higher remuneration for services in exchange for waiving claims against the contracting authority. Unarguably, the very fact of concluding a settlement based on which the parties modify a contract does not mean that Article 72 of Directive 2014/24/EU could not apply thereto. Otherwise, instead of concluding annexes, the parties would enter into settlements with the substantive content identical to annexes, thereby circumventing Directive 2014/24/EU. This was excluded in Case C-549/14 Finn Frogne, in which the parties to a contract concluded a settlement agreement under which the scope of the contract was significantly reduced. The Court ruled that:

25 Art 2(1)(19). In light of that definition, for instance, a fax is not treated as 'electronic means'. See the position of Multi-Stakeholder Expert Group on e-procurement available on the website: http://ec.europa.eu/DocsRoom/documents/ 20842/attachments/1/translations/en/renditions/pdf, p 15 (accessed on: 30.11.2020).

26 Arrowsmith (n 6), p 394. It is also submitted that 'it is not likely the case that the Procurement Directive is not applicable merely because the given agreement did not take place in writing'. See Risvig Hansen (n 3), p 186.

27 See also Recital 58, according to which:

While essential elements of a procurement procedure such as the procurement documents, requests for participation, confirmation of interest and tenders should always be made in writing, oral communication with economic operators should otherwise continue to be possible, provided that its content is documented to a sufficient degree. This is necessary to ensure an adequate level of transparency that allows for a verification of whether the principle of equal treatment has been adhered to.

This is confirmed in Art 22(2), which says:

oral communication may be used in respect of communications other than those concerning the essential elements of a procurement procedure, provided that the content of the oral communication is documented to a sufficient degree. For this purpose, the essential elements of a procurement procedure include the procurement documents, requests for participation, confirmations of interest and tenders. In particular, oral communications with tenderers which could have a substantial impact on the content and assessment of the tenders shall be documented to a sufficient extent and by appropriate means, such as written or audio records or summaries of the main elements of the communication. 
the fact that a material amendment of the terms of a contract results not from the deliberate intention of the contracting authority and the successful tenderer to renegotiate the terms of that contract, but from their intention to reach a settlement ... [cannot] provide justification for the decision to carry out that amendment without respecting the principle of equal treatment from which all operators potentially interested in a public contract must benefit. ${ }^{28}$

\section{PARTIES TO A CONTRACT}

1.20 The definition of a 'public contract' expressly states that 'one or more economic operators' and 'one or more contracting authorities' are the parties to a contract. ${ }^{29}$ Under Directive 2014/25/ EU, the parties are 'one or more economic operators' and 'one or more contracting entities'..$^{30}$ In addition, according to Directive 2014/23/EU, for a concession agreement to be concluded 'one or more contracting authorities or contracting entities' must entrust the execution of works or the provision of services to 'one or more economic operators'. ${ }^{31}$

1.21 It is necessary to distinguish between a 'contracting authority' and a 'contracting entity'. This distinction is a consequence of the separate regulation of Directive 2014/24/EU and Directive 2014/25/EU, and the difference between the notions of a public contract and procurement under these directives. Procurement within the meaning of Directive 2014/25/EU is the acquisition - by way of a contract - of work, supplies or services by at least one contracting entity from economic operators chosen by that contracting entity, where the work, supplies or services are intended for the pursuit of activities in the utilities sector, as referred to in Articles 8-14 of Directive 2014/25/EU. Activity in the utilities sector is of key importance in this context because Article 4(1) of Directive 2014/25/EU sets out that contracting entities are either contracting authorities or public undertakings pursuing one of the activities referred to in Articles 8-14, or perform one or more of the activities referred to in Articles 8-14 on the basis of special or exclusive rights granted by a competent authority of a Member State. This means that only entities operating in the utilities sector can be contracting entities. This is the main difference between a contracting authority and a contracting entity. ${ }^{32}$ Notably, contracting authorities may also be contracting entities.

1.22 It must be noted that there are three categories of 'contracting authority', namely the State, regional or local authorities, bodies governed by public law or associations formed by one or more such authorities; or one or more such bodies governed by public law. ${ }^{33}$ Whereas the notion of the State, regional or local authorities does not raise any doubts, the concept of

28 Judgment of the Court of 7 September 2016, Case C-549/14 Finn Frogne, ECLI:EU:C:2016:634, para 32.

29 See Art 2(1)(5).

30 See the definition of 'supply, works and service contract' set out in Art 2(1) of Directive 2014/25/EU.

31 See Art 5(1).

32 This is also highlighted in the definition of 'contracting authority' given in Art 6(1) of Directive 2014/23/EU:

For the purposes of this Directive, 'contracting authorities' means State, regional or local authorities, bodies governed by public law or associations formed by one or more such authorities or one or more such bodies governed by public law other than those authorities, bodies or associations which pursue one of the activities referred to in Annex II and award a concession for the pursuit of one of those activities.

See Annex II specifying types of activities in the utilities sector.

See Art 2(1)(1) of Directive 2014/24/EU. 
a 'body governed by public law' might. Under Directive 2014/24/EU 'bodies governed by public law' are bodies that have all of the following attributes:

- they are established for the specific purpose of meeting needs in the general interest, not having an industrial or commercial character;

- they have legal personality; and

- they are financed, for the most part, by the State, regional or local authorities, or by other bodies governed by public law; or are subject to management supervision by those authorities or bodies; or have an administrative, managerial or supervisory board of which more than half of the members are appointed by the State, regional or local authorities, or by other bodies governed by public law. ${ }^{34}$

These three features confirm the strict dependence of those bodies on the State, regional or local authorities. ${ }^{35}$

In the context of the definition of a body governed by public law, it is important to point out that Directive 2014/24/EU does not require that contracting authorities should only be public entities. Contracting authorities can also be entities that are private in terms of their status or legal nature. One should bear in mind, however, that entities operating under regular market conditions, which are profit-oriented and may incur losses from their business activity, should not be considered as 'bodies governed by public law'. This is because the needs in the general interest, which they have been set up to meet, or have been given the task of meeting, may be deemed to be industrial or commercial by nature. ${ }^{36}$

From the point of view of performing a contract, and in particular, modifying it, questions may be raised about the stage at which the contracting authority's status should be determined. For instance, it is possible that in the course of performing a contract, after a public procurement procedure has been initiated, a body governed by public law will no longer be financed for the most part by the State, regional or local authorities or other bodies governed by public law, or that its management will no longer be supervised, and members of its governing bodies will no longer be appointed, by such authorities or bodies. However, I agree with Sue Arrowsmith that the status of the contracting authority should be determined at the start of the award procedure. ${ }^{37}$ She rightly refers in this context to Article 4(4) of Directive 2014/24/EU, according to which the estimated value of procurements should also be determined at the moment at which the call for competition is sent or, if a call for competition is not foreseen, at the moment when the contracting authority commences the procurement procedure. This may be done, where appropriate, by contacting economic operators in relation to the procurement. In addition, the Court asserts that: ' $[t]$ he applicable directive is, as a rule, the one in force when the contracting authority chooses the type of procedure to be followed and decides definitively whether it is necessary for a prior call for competition to be issued for the award of a public contract'. ${ }^{38}$

34 See Art 2(1)(4).

35 See, for instance, the judgment of the Court of 3 October 2000 in Case C-380/98 University of Cambridge, ECLI:EU: C:2000:529, para 20. See more on 'bodies governed by public law' in Arrowsmith (n 6), pp 346-367.

36 See Recital 10 of Directive 2014/24/EU.

37 Arrowsmith (n 6), p 377.

38 See judgment of the Court of 11 July 2013, Case C-576/10 Commission v Netherlands, ECLI:EU:C:2013:510, para 52. 
1.26 In the CJEU's view, it would be contrary to the principle of legal certainty if the applicable law was determined by reference to the date of the award of the contract, since that date marks the end of the procedure, while the decision of the contracting authority to proceed with or without a prior call for competition is normally taken at the initial stage of that procedure. ${ }^{39}$ As a result, if on the start date of a public procurement procedure there is a contracting authority within the meaning of Directive 2014/24/EU, the subsequent loss of that status does not affect the application thereof, including to provisions concerning contract modification.

1.27 Directive 2014/24/EU provides for occasional joint procurement, where two or more contracting authorities may agree to carry out certain specific procurements jointly.

1.28 If the entire contract award procedure is carried out jointly on behalf and on account of all the contracting authorities concerned, they are also jointly liable for their obligations. The same applies when one contracting authority manages the procedure, acting on its own behalf and on behalf of the other contracting entities concerned. However, where not the entire procurement procedure is carried out in the name and on behalf of the contracting authorities concerned, they are jointly responsible only for those parts that are carried out jointly. Each contracting authority will then have sole responsibility for fulfilling its obligations pursuant to the directive in respect of the parts it conducts in its own name and on its own behalf. ${ }^{40}$

1.29 Apart from a contracting authority or contracting entity, a contract must have an economic operator as a party. Under Directive 2014/24/EU, 'economic operator' means: 'any natural or legal person or public entity or group of such persons and/or entities, including any temporary association of undertakings, which offers the execution of works and/or a work, the supply of products or the provision of services on the market'. ${ }^{41}$

1.30 Notably, Directive 2014/24/EU does not prevent a public entity from being the economic operator. It is expressly confirmed by the preamble to Directive 2014/24/EU, which states, among other things, that: ' $[\mathrm{t}]$ he sole fact that both parties to an agreement are themselves public authorities does not as such rule out the application of procurement rules'. ${ }^{42}$

1.31 In fact, there are no good reasons for preference in giving the status of economic operators to either public or private entities. ${ }^{43}$ However, the application of the procurement rules should not interfere with the freedom of public authorities to perform public service tasks conferred on them using their own resources, including the possibility of cooperation with other public authorities. Consequently, for instance, Article 12 of Directive 2014/24/EU provides for exclusions from its application to public contracts within the public sector.

1.32 The notion of 'economic operator' should be construed broadly so as to include any person and/ or entity that offers to carry out the work, to supply the products or to provide the services on the market, regardless of the legal form under which they have chosen to operate. Thus, firms,

39 Para 53. The principle of legal certainty is also referred to by Sue Arrowsmith (n 6), p 377.

40 See Art 38 of Directive 2014/24/EU.

41 See Art 2(1)(10).

42 See Recital 31.

43 Szydło (n 8), p 107. 
branches, subsidiaries, partnerships, cooperative societies, limited companies, universities, public or private, and other forms of entity, save for natural persons, should all fall within the notion of an economic operator, whether or not they are 'legal persons' in all circumstances. ${ }^{44}$ Article 19(1) of Directive 2014/24/EU is conclusive here, establishing that economic operators under the law of the Member State in which they are established are entitled to provide the relevant service, and that they will not be rejected solely because, under the law of the Member State in which the contract is awarded, they would be required to be either natural or legal persons.

It is worth noting that under Directive 2014/24/EU, an economic operator is an entity that 'offers' to carry out the work, to supply the products or to provide the services. Hence, it might seem that the economic operator is only an entity at the stage of awarding the public contract (i.e., precisely at the time when it is offering to carry out the work, to supply the products or to provide the services). However, the term 'economic operator' is also used in provisions concerning contract modification. ${ }^{45}$ As a result, the 'economic operator' is both an entity that participates in a contract award procedure and an entity whose tender has been selected and who is performing the contract. At the same time, Directive 2014/24/EU gives definitions of a 'candidate' and 'tenderer' to help differentiate between the two situations. And so, a 'candidate' means an economic operator that has sought an invitation or has been invited to take part in a restricted procedure, a competitive procedure with negotiation, a negotiated procedure without prior publication, a competitive dialogue or an innovation partnership, ${ }^{46}$ whereas a 'tenderer' means an economic operator that has submitted a tender. ${ }^{47}$

As mentioned above, the definition of 'economic operator' also includes a group of natural or legal persons, or a group of public entities, including 'temporary associations of undertakings', often called a consortium. This is confirmed by Article 19(2) of Directive 2014/24/EU, whereby: ' $[\mathrm{g}]$ roups of economic operators, including temporary associations, may participate in procurement procedures'. It further stipulates more precisely that contracting authorities cannot require them to have a specific legal form in order to submit a tender or a request to participate.

However, a consortium is not a party to a contract - the party are the economic operators who jointly sought to be awarded a contract, and then are jointly performing it. Consequently, changes of parties comprising a consortium after a contract has been awarded may potentially be a modification of that contract.

A subcontractor is not a party to a contract either, but a change of a subcontractor may also be important in the context of contract modification. This was highlighted by the CJEU's judgment in Case C-91/08 Wall, even before the public procurement directives came into effect. The Court stated then that:

[a] change of subcontractor, even if the possibility of a change is provided for in the contract, may in exceptional cases constitute such an amendment to one of the essential provisions of a concession

44 See Recital 14 of Directive 2014/24/EU.

45 See, for instance, Art 72(1)(b) or (d) of Directive 2014/24/EU.

46 See Art 2(1)(12).

47 See Art 2(1)(11). 
contract, where the use of one subcontractor rather than another was, in view of the particular characteristics of the services concerned, a decisive factor in concluding the contract. ${ }^{48}$

1.37 Such a change could also be considered substantial under the public procurement directives. ${ }^{49}$ The difference in relation to the judgment in Case C-91/08 Wall is that it would be irrelevant if the contracting authority had provided for the possibility of such a change in the procurement documents..$^{50}$

1.38 Last but not least, it should be mentioned that both parties, that is, the contracting authority and the economic operator, may request a contract modification. Such modifications may be favourable for both parties or only one of them. Undeniably, though, modifications that are favourable for the contracting authority are more likely to be considered compliant with the EU law provisions. This is because provisions concerning contract modifications were adopted in order to protect the principles of non-discrimination, equal treatment and transparency. They are to prevent favouring the economic operator to whom a public contract has been awarded. Therefore, a modification that is favourable for the contracting authority is more likely to be considered as not substantial within the meaning of Article 72(1)(e) of Directive 2014/24/EU than a modification favourable for the economic operator. ${ }^{51}$

\section{E. SUBJECT MATTER OF A CONTRACT}

1.39 According to the definition of a public contract, the subject matter of a contract is 'the execution of works, the supply of products or the provision of services'. This means that the EU public procurement rules are not intended to apply to all forms of spending public funds, but only those where the purpose is to acquire works, supplies or services for consideration by means of a public contract. ${ }^{52}$ Consequently, Directive 2014/24/EU contains definitions of 'public works contracts', 'public supply contracts' and 'public service contracts'. The first definition, i.e., that of a public works contract, is particularly important. It is referred to in the definition of 'public service contract' - the object of which is the provision of services other than those specified in the definition of a 'public works contract'. According to Article 2(1)(6) of Directive 2014/24/ EU, public works contracts mean:

public contracts, having as their object one of the following: (a) the execution, or both the design and execution, of works related to one of the activities within the meaning of Annex II; (b) the execution, or both the design and execution, of a work; (c) the realisation, by whatever means, of a work corre-

48 Judgment of the Court of 13 April 2010, Case C-91/08 Wall, ECLI:EU:C:2010:182, para 39.

49 See, for instance, Art 72(4)(a) of Directive 2014/24/EU, which provides that a substantial contract modification is: the modification [that] introduces conditions which, had they been part of the initial procurement procedure, would have allowed for the admission of other candidates than those initially selected or for the acceptance of a tender other than that originally accepted or would have attracted additional participants in the procurement procedure.

In the judgment of the Court of 13 April 2010, Case C-91/08 Wall, ECLI:EU:C:2010:182, the Court deemed a change of a subcontractor to be 'such an amendment' (para 38).

50 For more details see Section C.2 in Chapter 3.

51 Provided that in a specific case it will be possible to distinguish who the modification favours.

52 See Recital 4 of Directive 2014/24/EU. 
sponding to the requirements specified by the contracting authority exercising a decisive influence on the type or design of the work. ${ }^{53}$

In the CJEU's view, the notion of 'public works contract' does not require that the works forming the subject of the contract be materially or physically carried out for the contracting authority, provided that they are carried out for that authority's immediate economic benefit. However, the latter condition is not satisfied through that contracting authority exercising regulatory urban-planning powers. ${ }^{54}$

In turn, 'public supply contracts' mean public contracts for the purchase, lease, rental or hire purchase of products, with or without an option to buy. Public supply contracts may additionally include siting and installation operations.

There are at least three reasons why the division of the subject of a public contract into works, services and supplies is important. ${ }^{55}$ First of all, there are different thresholds triggering the application of a given directive: definitely higher for works than for services or supplies. ${ }^{56}$ Second, there are different exclusions of applying Directive 2014/24/EU: the broadest for services, for which specific exclusions are stipulated. ${ }^{57}$ Third, a special, more relaxed regime for awarding contracts is envisaged for social and other specific services. ${ }^{58}$ For those reasons, Directive 2014/24/EU regulates mixed procurement, which includes contracts that have at least two types of procurement (works, services or supplies) as their subject matter. The EU lawmaker has decided that such contracts will be awarded in accordance with the provisions applicable to the type of procurement that corresponds to the main subject of the contract in question. ${ }^{59}$ The main subject of a given contract is also important if different parts of the contract are objectively not separable. ${ }^{60}$ The determination as to whether different parts are separable or not should be carried out on a case-by-case basis, taking into account not only the express or presumed intentions of the contracting authority to regard the various aspects making up a mixed contract as indivisible, but also objective evidence capable of justifying that intention and of establishing the need to conclude a single public contract. The need to award a single public contract may be due to both technical and economic reasons. ${ }^{61}$

It is worth noting that Directive 2014/24/EU does not regulate contract modifications differently depending on the subject of the modification. This is clearly seen in Article 72(1)(b), which expressly refers to additional works, services and supplies.

'A work', according to Art 2(1)(7) of Directive 2014/24/EU, means the outcome of building or civil engineering works taken as a whole which is sufficient in itself to fulfil an economic or technical function.

Judgment of the Court of 25 March 2010, Case C-451/08 Helmut Müller, ECLI:EU:C:2010:168, para 58.

Naturally, there may be other differences, to mention only different grounds for awarding a contract for works, services or supplies by way of a negotiated procedure without prior publication (Art 32(3)-(5) of Directive 2014/24/EU). Below, I focus on what are, in my opinion, the most important ones.

See Art 4 of Directive 2014/24/EU.

See Art 10 of Directive 2014/24/EU.

See Arts 74-77 of Directive 2014/24/EU.

See Art 3(2) of Directive 2014/24/EU.

See Art 3(6) of Directive 2014/24/EU.

Recital 11 of Directive 2014/24/EU. 
1.44 However, the subject of a public contract may be significant from the point of view of the permissibility of contract modifications. As will be explained in detail in Chapter 3, one of the key notions under Directive 2014/24/EU in the context of modifications is the 'overall nature of the contract', which limits the possibility of modifying contracts in the case of modifications envisaged by review clauses, modifications due to unforeseen circumstances or de minimis modifications. Unfortunately, this term, despite its significance, has not been defined in Directive 2014/24/EU. Ahead of further discussion, it should be pointed out that this notion relates, among other things, to the subject matter of a public contract. As a result, changing a public works contract into a public service contract would be to change its overall nature. Recital 109 to Directive 2014/24/EU clearly confirms that: "[ $t$ ] his cannot apply in cases where a modification results in an alteration of the nature of the overall procurement, for instance by replacing the works, supplies or services to be procured by something different or by fundamentally changing the type of procurement'.

\section{F. TERM OF VALIDITY OF A CONTRACT}

1.45 The definition of a 'public contract' does not make a reference to its term. However, the term of validity of a contract is important from the point of view of its modification, to mention only the title of Article 72 of Directive 2014/24/EU, which refers to the 'modification of contracts during their term'. A change, and in particular, an extension of the term of a contract may in many cases mean a substantial modification of a contract, which will require an additional justification in order to be valid. ${ }^{62}$ Nevertheless, Directive 2014/24/EU - unlike Directive 2014/23/EU - does not have a separate regulation regarding the term of a contract. Article 18(1) of the latter directive provides that concessions have a limited duration that is defined by a contracting authority or contracting entity on the basis of works or services contracted to the concessionaire. The preamble clarifies that the limited duration of a concession is intended to prevent market foreclosure and the restriction of competition. ${ }^{63}$ No provision of Directive 2014/23/EU determines the maximum term of a concession contract. The EU lawmaker seems to accept that it may be a very long term, ${ }^{64}$ definitely longer than the five-year term mentioned in Article 18(2) of Directive 2014/23/EU, even if this could lead to market foreclosure, and consequently pose an obstacle to the freedom of establishment and the freedom to provide services. ${ }^{65}$ A longer term may be justified if it is necessary for the concessionaire to recoup the investments made on works or services with a return on the invested capital taking into account investments required to achieve specific contractual objectives. ${ }^{66}$ Similar rules should apply to the extension of concession contracts concluded for more than five years. Contracting authorities or entities will not have the right to extend concession contracts even if they provide so

62 For more detail see Chapter 3.

63 Recital 52 of Directive 2014/23/EU. This position has been presented earlier in the case law, for instance, in the judgment of the Court of 25 March 2010, Case C-451/08 Helmut Müller, ECLI:EU:C:2010:168, para 78 in which the Court concluded that: '[w]ith regard to the duration of concessions, there are serious grounds, including the need to guarantee competition, for holding the grant of concessions of unlimited duration to be contrary to the European Union legal order'.

64 See also Recital 75 of Directive 2014/23/EU. Concession contracts typically involve long-term and complex technical and financial arrangements which are often subject to changing circumstances.

65 Ibid.

66 See Art 18(2). 
in clear, precise and unequivocal review clauses, unless the extension is needed in order for the concessionaire to recoup investments made.

It seems that contracts regulated by Directive 2014/24/EU may be concluded for both a fixed and indefinite term. ${ }^{67}$ However, in Case C-454/06, the Court concluded that the practice consisting of awarding public contracts for an indefinite term is in itself at odds with the scheme and purpose of the Community rules governing public contracts' ${ }^{\prime 68}$ and 'might, over time, impede competition between potential service providers and hinder the application of the provisions of Community directives governing the advertising of procedures for the award of public contracts'. ${ }^{69}$ It finally admitted that, at that stage, the EU law did not prohibit the conclusion of public service contracts for an indefinite term. ${ }^{70}$

Directive 2014/24/EU does not introduce any restrictions as to the type of contract that may be concluded for an indefinite term. In the case of contracts for a fixed term, the term affects the way the estimated contract value is calculated. For instance, with respect to public supply contracts relating to the leasing, hire, rental or hire purchase of products, contracts with a term of 12 months or less are different from contracts with a term longer than 12 months. There is also a limitation as to the term of a public supply contract in the case of the negotiated procedure without prior publication: the term of contracts providing for additional deliveries by the original supplier, as well as any recurring contracts, should not, as a rule, exceed three years. ${ }^{71}$

Whenever possible, the planned term of a contract should be set out already in the contract notice. $^{72}$

As mentioned above, the term of a contract and the related period of the contract performance by the economic operator, corresponding, for instance, to the period of providing services or executing works, is highly significant from the point of view of contract modification. As a rule, it should be assumed that a change of a contract term, in particular its extension, should be treated as a substantial contract modification. A substantial modification may, in particular, introduce conditions that, had they been part of the initial procurement procedure, would have allowed for the admission of candidates other than those initially selected, or for the selection of a tender other than that originally accepted, or would have attracted additional participants in the procurement procedure (Art 72(4)(a) of Directive 2014/24/EU). For instance, if an economic operator had known that the period of performing a contract would be longer, it might have priced a tender differently, or the procedure might have attracted economic operators who decided not to request to participate in a procedure or submit a tender precisely because of the term of the contract (if they viewed it as too short). As a result, if the contracting authority has not provided for a possible change of the term in the procurement documentation and there is no basis for determining that a modification is a result of unforeseen circumstances, it may be impossible to make such contract modification.

See, in particular, Art 5(12) of Directive 2014/24/EU concerning the method for calculating the estimated value of procurement. This does not relate to framework agreements which may be concluded only for a fixed term. Judgment of the Court of 19 June 2008, Case C-454/06 pressetext Nachrichtenagentur, ECLI:EU:C.2006:304, para 73.

69 Ibid.

70 Ibid., para. 74

71 See Art 32(3)(b) of Directive 2014/24/EU.

72 See Annex V, Part C, Section 10 of Directive 2014/24/EU. 


\section{G. TERMINATION OF A CONTRACT}

1.50 For the first time in history, Directive 2014/24/EU now regulates the issue of contract termination. The EU lawmaker explained the need for such provisions as follows:

contracting authorities are sometimes faced with circumstances that require the early termination of public contracts in order to comply with obligations under Union law in the field of public procurement. Member States should therefore ensure that contracting authorities have the possibility, under the conditions determined by national law, to terminate a public contract during its term if so required by Union law. ${ }^{73}$

1.51 It is submitted that the new rules are to prevent attempts by Member States to invoke their national law or general legal principles (such as the principle of legal certainty or the protection of legitimate expectations) in order to demonstrate that it would not be possible to terminate an unlawful contract. ${ }^{74}$

1.52 According to Article 73 of Directive 2014/24/EU, Member States must ensure that contracting authorities are able to terminate a public contract during its term in at least three situations and on conditions set out in applicable national law. ${ }^{75}$ First of all, a contract may be terminated if it has been substantially modified in a way that would have required a new procurement procedure pursuant to Article 72. Second, a contract may be terminated if, at the time of awarding the contract, the contractor was in one of the situations referred to in Article 57(1), and therefore, should have been excluded from participation in the procurement procedure. Finally, a contract may be terminated if it should not have been awarded to the contractor in view of a serious infringement of the obligations under the Treaties and Directive 2014/24/EU, as declared by the Court in a procedure pursuant to Article 258 of the TFEU. ${ }^{76}$

1.53 Tobias Indén correctly emphasises that a possible explanation for the absence in the previous public procurement directives of rules relating to contract termination could be that those directives in general did not regulate the issue of contract performance. ${ }^{77}$ The situation changed after the new public procurement directives came into effect. Regrettably, the new legislation raises numerous doubts.

74 See Kirsi-Maria Halonen, 'Termination of a public contract: Lifting the veil on Article 73 of 2014/24 Directive' (2017) PPLR, Issue 4, p 190, who refers to the judgment of the Court of 18 July 2007, Case C-503/04 Commission v Germany, ECLI:EU:C:2007:432.

75 In fact, these three cases could be reduced to two categories: a substantial modification of the contract and unlawful award of the contract to the contractor.

76 Interestingly, Art 44(c) of Directive 2014/23/EU has slightly different wording:

$[\mathrm{M}]$ ember States shall ensure that contracting authorities and contracting entities have the possibility, under the conditions determined by the applicable national law, to terminate a concession during its term, where ... the Court of Justice of the European Union finds, in a procedure pursuant to Article 258 TFEU, that a Member State has failed to fulfil its obligations under the Treaties by the fact that a contracting authority or contracting entity belonging to that Member State has awarded the concession in question without complying with its obligations under the Treaties and this Directive.

In comparison to Art 73(c) of Directive 2014/24/EU, a contract may be terminated on the grounds of any infringement and not only a 'serious infringement'.

77 Tobias Indén, 'Comments to Article 73' in Michael Steinicke, Peter L. Vesterdorf, Brussels Commentary on EU Public Procurement Law (Verlag C.H. Beck 2018), p 776. 
First and foremost, Article 73 only gives examples of reasons justifying contract termination. The expression 'at least under the following circumstances' leaves no doubt of this. ${ }^{78}$ In this context, it is not clear why, for instance, the requirement to conduct a new award procedure as a result of a substantial contract modification has been 'singled out' in relation to other cases where the contracting authority, contrary to Directive 2014/24/EU, has awarded a contract without prior publication of a contract notice in the Official Journal of the European Union. ${ }^{79}$ If a contract is awarded without prior publication of a notice, then according to Article $2 \mathrm{~d}(1)$ (a) of Directive $89 / 665 / \mathrm{EEC}$, the Member States should ensure that the contract is considered ineffective by a review body independent of the contracting authority, or that its ineffectiveness will result from a decision of the review body. Hence, Article 73 of Directive 2014/24/EU appears to be an additional regulation that may result in the 'expiry' of a contract concluded between a contracting authority and an economic operator. ${ }^{80}$ Thanks to Article 73 the contracting authority has a choice - it may terminate the contract without waiting for the outcome of the procedure referred to in the directives. It should be possible to terminate a contract each time a contract has been unlawfully awarded, or at least, whenever it is possible to consider a contract as ineffective. ${ }^{81}$ Given the above, it is not clear why those three particular grounds were chosen by the EU lawmaker. ${ }^{82}$ In theory, the provisions implementing Article 73 of Directive 2014/24/EU to national laws could list other grounds for terminating contracts, and not only those expressly listed in Article 73. In practice, many Member States have decided to transpose Article 73 into national law literally. ${ }^{83}$

Another issue is that contracting authorities only have a 'possibility' to terminate a public contract during this term. Recital 112 of Directive 2014/24/EU seems particularly unfortunate in this context because on the one hand it speaks about 'the possibility [...] to terminate a public contract during its term', and on the other hand 'if so required by Union law'. Since it is 'required' under EU law to terminate a contract in certain circumstances, then it would seem that the contracting authority should be required to terminate a contract and not only

78 See also Recital 110 of Directive 2014/24/EU: “[i]n line with the principles of equal treatment and transparency, the successful tenderer should not, for instance where a contract is terminated because of deficiencies in the performance, be replaced by another economic operator without reopening the contract to competition'. Hence, it seems to accept that a contract may be terminated 'because of deficiencies in [its] performance'.

79 Arrowsmith (n 6), p 604.

80 Wojciech Hartung, Michał Bagłaj, Tomasz Michalczyk, Michał Wojciechowski, Jakub Krysa, Katarzyna Kuźma, Dyrektywa Parlamentu Europejskiego i Rady 2014/24/EU w sprawie zamówień publicznych. Komentarz (C.H. Beck 2015), comments to Article 73, Nb 2.

81 Arrowsmith (n 6), p 604.

82 In particular, given that those grounds are not homogenous, for instance, for the ground laid down in Art 73(c) to be effective, it requires a prior judgment from the Court, whereas the two remaining grounds do not require any prior decision of any body. See Mari Ann Simovart, 'The power of termination under Article 73(a) of Directive 2014/24/EU: The challenge of balancing implementation' (2018) PPLR, Issue 6, p 280.

83 See Steen Treumer, Mario Comba, 'Trends in the implementation of Directive 2014/24: Minimalism and narrow interpretations' in Steen Treumer, Mario Comba, Modernising Public Procurement: The Approach of EU Member States (Edward Elgar Publishing 2018), p 325. See also Halonen (n 74), pp 190-193. The transposition in Poland was similar, however, the contracting authority may also rescind from the contract in the event of a material change of circumstances resulting in the performance of the contract no longer being in the public interest, which could not have been foreseen at the time of its conclusion, or if the further performance of the contract may threaten the essential interest of national security or public safety. In such circumstances, the contracting authority may rescind from the contract within 30 days of becoming aware of these circumstances. 
have a possibility (right) of doing so. ${ }^{84}$ Notably, the opinion that it is necessary to terminate a contract in certain circumstances was also expressed by the Court long before Directive 2014/24/EU entered into force. ${ }^{85}$ Why, therefore, did the EU lawmaker not decide to impose an obligation on the contracting authority to terminate a contract in the circumstances set out in Directive 2014/24/EU? Some possible explanations are proposed below.

1.56 First of all, as already mentioned, Article 73 of Directive 2014/24/EU needs to be considered in the context of the Remedies Directive. Since there are other ways of terminating cooperation between the parties, other than by terminating a contract, the contracting authority should not, as a rule, be required to terminate contracts in the circumstances contemplated in Directive 2014/24/EU. ${ }^{86}$ In some cases, the contracting authority might even want to wait for a court decision before deeming a contract ineffective. ${ }^{87}$ If an appeal (complaint, action) is dismissed because the Court concludes that public procurement laws have not been breached, it would be hard to expect the contracting authority to decide to terminate the contract with the economic operator. At the same time, it is also argued that the 'possibility' referred to in Article 73 of Directive 2014/24/EU may become an 'obligation' only if the Court or a national court confirms a serious breach of law and it is not or cannot (e.g., due to the lapse of time) be determined that the contract is ineffective..$^{88}$

1.57 On the other hand, it is worth noting that the obligation to consider a contract as ineffective does not have to be absolute. According to Article 2d(3) of the Remedies Directive, Member States may decide that a review body independent of the contracting authority may not deem a contract ineffective even though it has been awarded unlawfully on the grounds specified in Article $2 \mathrm{~d}(1)$ of that directive if the review body finds, having examined all relevant aspects, that overriding reasons relating to a general interest require that the effects of the contract should be maintained. A question may arise as to what extent similar circumstances may give the contracting authority a reason to decide not to terminate the contract, in particular in a situation where Article 73 of Directive 2014/24/EU is silent on the subject. It seems that contracting authorities should have the right to determine whether contract termination will be

84 See also Simovart (n 82), p 280, calling it a 'logical approach'.

85 Judgment of the Court of 18 July 2007, Case C-503/04 Commission v Germany, ECLI:EU:C:2007:432. More about this judgment in Chapter 5 .

86 See also judgment of the Court of 13 April 2010, Case C-91/08 Wall, ECLI:EU:C:2010:182, para 65 in which the Court held as follows:

It follows that the principles of equal treatment and non-discrimination on grounds of nationality [...] and the consequent obligation of transparency do not require the national authorities to terminate a contract or the national courts to grant a restraining order in every case of an alleged breach of that obligation in connection with the award of service concessions. It is for the domestic legal system to regulate the legal procedures for safeguarding the rights which individuals derive from that obligation in such a way that those procedures are no less favourable than similar domestic procedures and do not make the exercise of those rights practically impossible or excessively difficult.

87 Similarly, Halonen ( $\mathrm{n} 74$ ), who notes that there may be difficulties with, for instance, determining whether a modification is substantial; and if a contract is terminated because allegedly, it has been substantially modified, the contracting authority must be prepared that the economic operator will challenge such decision. See also Mari Ann Simovart (n 82), p 285.

88 Halonen, ibid. It seems this view is also shared by Sue Arrowsmith, The Law of Public and Utilities Procurement: Regulation in the EU and UK, Volume 2 (Sweet \& Maxwell 2018), p 1041. Well before Directive 2014/24/EU came into force, Steen Treumer had drawn attention to the obligation to terminate a public contract if the Court or a national court declares a major infringement, in 'The discretionary powers of contracting entities: Towards a flexible approach in the recent case law of the European Court of Justice?' (2006) PPLR, Issue 4, pp 80-82. 
a necessary and appropriate measure in a specific case. ${ }^{89}$ According to Article 18 of Directive 2014/24/EU, the contracting authority should act in a proportionate manner. One must remember, however, that under the Remedies Directive, if the review body does not deem a contract ineffective, it should impose a fine on the contracting authority. ${ }^{90}$ However, if the contracting authority decides not to terminate the contract, this contract will simply continue to be in force and none of the parties, and in particular, the contracting authority will bear any adverse consequence on that account.

Second, the principle of proportionality may be another reason why the EU lawmaker provides for mere possibility to terminate a contract, rather than obligation. Based on Article 5(4) of the TEU, the content and form of the Union's action should not exceed what is necessary to achieve the objectives of the Treaties. Steen Treumer points out that, in addition to the public interest, the contracting authority should take the following into account: whether the breach of contract is sufficiently serious, the contract's significance from the internal market perspective (the longer the contract and the higher its value, the larger its potential significance), the degree of completion and the parties' interests. ${ }^{91}$

In this context, it is not clear if the position presented by the Court in Case C-454/06, whereby 'a clause by which the parties undertake not to terminate for a given period a contract concluded for an indefinite period is not automatically considered to be unlawful under Community law governing public procurement' is still valid. ${ }^{92}$ Accepting that one is dealing 'only' with the contracting authority's right to terminate a contract, there would seem to be no reason why the contracting authority should limit the right for itself (subject to the provisions concerning competition law). On the other hand, it is important to bear in mind that, as mentioned above, the EU lawmaker itself seems to claim that in certain circumstances a contract must be terminated.

Contract termination takes place on conditions applicable in the national legislation. ${ }^{93}$ This means that a national legislator should, for instance, resolve whether a contract will be terminated by a notice of termination or rescinded, and as a result what legal effects it will have (ex tunc or ex nunc), ${ }^{94}$ and whether a contract will be terminated effective immediately or upon the lapse of a certain period. However, the national legislator's freedom is not unlimited, at least in some cases. For instance, it seems that the termination of a contract after the lapse of a certain period of time is possible only in exceptional circumstances (e.g., when it is necessary to ensure supplies, services or works until another economic operator is selected in compliance

89 Similarly, Simovart (n 82), pp 284-285.

90 See Section B.3 in Chapter 5.

91 Steen Treumer, 'Remedies and enforcement' in Sue Arrowsmith (ed), EU Public Procurement Law: An Introduction (University of Nottingham 2010), pp 379-382. In this context, see also Piotr Bogdanowicz, 'The application of the principle of proportionality to modifications of public contracts' (2016) EPPPL, Issue 3, pp 194-204.

92 Judgment of the Court of 19 June 2008 in Case C-454/06 pressetext Nachrichtenagentur, ECLI:EU:C:2006:304, para 75.

93 In addition, the parties to a public contract may provide in the contract itself for a number of important consequences in the event of its termination, e.g., the obligation to pay compensation by the party responsible for the termination.

94 In this respect, see also Art 2d(2) of Directive 89/665/EEC, which provides for the consequences of a contract being considered ineffective if the national law may provide for the retroactive cancellation of all contractual obligations or limit the scope of the cancellation to those obligations that still have to be performed. In the latter case, Member States should provide for the application of other penalties within the meaning of $\operatorname{Art} 2 \mathrm{e}(2)$. 
with public procurement $\left.\mathrm{law}^{95}\right)$. As a rule, termination should have an immediate effect because a breach continues during the notice period. ${ }^{96}$

1.61 National legislators may provide for other circumstances that would require the termination of a contract, for instance, when an economic operator's tender, which was selected as the most advantageous one, should have been rejected..$^{97}$

1.62 Article 73 of Directive 2014/24/EU concerns the termination of a contract by the contracting authority. From the perspective of European law, there are no reasons why the economic operator could not be the 'initiating' party (i.e., terminating or rescinding a contract). A contract may also be terminated by mutual agreement. ${ }^{98}$

1.63 As mentioned above, Article 73 of Directive 2014/24/EU mentions three grounds for terminating a contract. The first one, referred to in Article 73(a) of Directive 2014/24/EU - contract termination in the event of its substantial modification that would require a new procurement procedure under Article 72, will be discussed in detail in Chapter 5. At this stage, it suffices to say that, contrary to the literal wording of Article 73(a), which could suggest that the entire contract is terminated in each and every case, this provision should be read as concerning also the impermissible modification, and not the entire contract, depending on the circumstances. ${ }^{99}$ It is indisputable, however, that the two other grounds for termination, mentioned in Article 73 of Directive 2014/24/EU, apply to the entire contract.

1.64 Under Article 73(b), the contracting authority may terminate a contract if the economic operator's status was as described in Article 57(1) of Directive 2014/24/EU. ${ }^{100}$ In this way, the EU lawmaker gives a contracting authority a chance to remedy its mistake of failing to exclude the economic operator at the stage of a procurement procedure. Interestingly, the EU lawmaker did not make a reference in Article 73(b) to Article 57(2), which also provides for obligatory exclusion of an economic operator from a procurement procedure in the circumstances specified in that article. ${ }^{101}$ However, this does not stop the Member States from providing in their legal regimes that a contracting authority may terminate a contract also in the circumstances referred to in Article 57(2), or even Article 57(4) concerning discretionary grounds of exclusion of an economic operator from a procedure. By the way, a situation whereby an economic operator was subject to obligatory exclusion from a procedure, but the contracting authority did not exclude this economic operator from the public procurement procedure, instead concluding

95 Unless in this case a contract modification was possible.

96 Judgment of the Court of 18 July 2007, Case C-503/04 Commission v Germany, ECLI:EU:C:2007:432, para 29 in which the Court concluded that 'the adverse effect on the freedom to provide services arising from the disregard of the provisions of Directive 92/50 subsists throughout the entire performance of the contracts concluded in breach thereof.

97 Steen Treumer, 'Towards an obligation to terminate contracts concluded in breach of the EC public procurement rules: The end of the status of concluded contracts as sacred cows?' (2007) PPLR, Issue 6, p 368.

98 See, however, the resolution of the National Appeal Chamber (Poland) of 15 July 2020 no. KIO/KD 39/20 in which the Chamber held that this is not possible.

99 See Arrowsmith, Vol 2 (n 88), p 1041 and, in principle, Halonen (n 74), p 195.

100 Art 57(1) provides that contracting authorities must exclude an economic operator from participation in a procurement procedure if they have established, by verifying in accordance with Arts 59, 60 and 61, or are otherwise aware that that economic operator has been the subject of a conviction by final judgment for reasons contemplated in that article.

101 This concerns a breach of tax or social security obligations. 
a contract therewith, which it is then not required to terminate (but has a right do so), confirms the concerns raised above about Article 73. ${ }^{102}$

Similar doubts are also connected with the third ground - concerning a situation where a contract should not have been awarded to the economic operator because of a serious breach of obligations under the Treaties and Directive 2014/24/EU, which has been declared by the Court in a procedure under Article 258 TFEU. Also here, Directive 2014/24/EU does not require the contracting authority to terminate a contract, but merely grants it the 'possibility'.

Article 73(c) of Directive 2014/24/EU is the only one that makes contract termination dependant on an external event - in this case, a ruling by the Court after the Commission brings the matter to court on the grounds of Article 258 of the TFEU. According to Article 258 of the TFEU, if the Commission considers that a Member State has failed to fulfil an obligation under the Treaties, it will deliver a reasoned opinion on the matter after giving the State concerned the opportunity to submit its observations. If the State concerned does not comply with the opinion within the period laid down by the Commission, the latter may bring the matter before the Court. ${ }^{103}$ If the Court upholds the Commission's position, the State is required to take necessary measures to comply with the judgment. ${ }^{104}$ The manner of implementing the judgment, including, for instance, a decision on whether it is necessary to terminate a contract or not, is up to the Member State concerned. If, however, the Commission considers that the Member State has not taken measures ensuring compliance with the judgment, it may bring another case to Court specifying a lump sum or regular penalty payment to be made by that State. ${ }^{105}$

This ground will also be discussed in detail in Chapter 5. An impermissible contract modi-

fication may also be the basis for the procedure under Article 258 of the TFEU, and hence, be subject to termination under Article 73(c). Thus, there is a partial overlap between the application of Article 73(a) and Article 73(c). It also seems that, although the Commission very effectively enforces its rights under Article 258 of the TFEU, in practice, the grounds for the termination of a contract under Article 73(c) can be used only sporadically. The Commission's proceedings against a Member State concerning public contracts are very rare, and this will probably be no different for modifications of such contracts. It is because, infringement proceedings, including the pre-court phase, usually take a very long time to reach a conclusion, as much as several years.

102 However, it is important to bear in mind that Member States may, in extraordinary circumstances, provide for an exception from the exclusion requirement under Art 57(1) and (2) because of overriding reasons relating to the public interest, such as public health or environmental protection. In this case Art 73(b) will not apply.

103 A similar right to bring a matter to Court is also available to other Member States under Art 259 TFEU. Interestingly, Art 73(c) of Directive 2014/24/EU does not make a reference to that article. The reason may, in practice, be that Member States hardly ever bring matters to court against other Member States. Additionally, none of the matters brought to court so far has concerned public procurement.

104 Art 260(1) of the TFEU.

105 Art 260(2) of the TFEU. 


\section{H. FRAMEWORK AGREEMENT}

1.68 Article 72(1) of Directive 2014/24/EU concerns not only modifications of 'contracts' but also of 'framework agreements'. Therefore, one should consider what the term 'framework agreements' means and how this notion is regulated in the EU procurement law.

1.69 Framework agreements are dealt with in Article 33 of Directive 2014/24/EU. According to the second paragraph of Article 33(1), a framework agreement is an agreement between one or more contracting authorities and one or more economic operators, the purpose of which is to establish the terms governing contracts to be awarded during a given period, in particular with regard to price and, where appropriate, the quantity. A framework agreement may be entered into with one economic operator, with subsequent contracts being awarded on terms set out in the framework agreement (Art 33(3)), or with more than one economic operator, though Directive 2014/24/EU does not set any limit on the maximum number of economic operators. In the latter case, a framework agreement may be performed as follows: without reopening a competition procedure for a contract, by partly reopening the procedure and partly after opening a competition procedure, or by resubmitting a contract to a competition procedure (Art 33(4)). ${ }^{106}$

1.70 The term of a framework agreement does not exceed four years, save in exceptional cases that are duly justified, in particular by the subject of the framework agreement. ${ }^{107}$ As regards the term of individual contracts under the framework agreement, while they must be awarded before the end of the term of the framework agreement itself, their duration does not need to coincide with the duration of the framework agreement. The duration of such contracts should be determined taking into account such aspects as the time needed for their completion, where the maintenance of equipment with an expected useful life of more than four years is included, or where extensive training of staff to perform the contract is needed. ${ }^{108}$

1.71 As mentioned above, the purpose of a framework agreement is to determine the conditions of contracts to be awarded during a given period. Those conditions may, for instance, concern the price or anticipated amounts of services or supplies. Directive 2014/24/EU does not state how detailed those conditions should be. However, it is submitted in the literature that 'from the point of view of Directive 2014/24/EU, a framework agreement may be structured in such a way that it will be possible to consider it as a public contract sensu stricto'. ${ }^{109}$ This view, at least under the previous public procurement directives, was also shared by the Commission, which

106 For a more detailed discussion of advantages and disadvantages of framework agreements see Marta Andrecka (now Andhov), 'Framework agreements, EU procurement law and the practice' (2015) Procurement Law Journal, Issue 2, pp 130-133.

107 See the third paragraph of Art 33(1) of Directive 2014/24/EU.

108 See Recital 62 of Directive 2014/24/EU. It seems that the EU lawmaker should have stipulated that the term of individual contracts under a framework agreement can be longer than the term of the framework agreement itself in a place other than the preamble, for instance in Art 33. See also Steen Treumer, 'Evolution of the EU public procurement regime: The new Public Procurement Directive' in Lichère, Caranta, Treumer (eds) (n 2), pp 22-23.

109 This is noted by Wojciech Hartung, Michał Bagłaj, Tomasz Michalczyk, Michał Wojciechowski, Jakub Krysa, Katarzyna Kuźma, Dyrektywa Parlamentu Europejskiego i Rady 2014/24/EU w sprawie zamówień publicznych. Komentarz (C.H. Beck 2015), comments to Article 33, Nb 6. 
differentiated between 'framework contracts' and 'framework agreements stricto sensu' ${ }^{110}$ Yet, the current approach in this regard is inconsistent. On the one hand, Article 33 of Directive 2014/24/EU, in principle, separates framework agreements from contracts, also differentiating between 'framework agreements' and 'individual contracts'. A good example also comes from Article 72, which speaks about modifications of framework agreements separately from modifications of contracts (even though they are regulated in the same way - at least formally). On the other hand, there is Article 33(4)(a) of Directive 2014/24/EU, which provides that if a framework agreement is concluded with more than one economic operator, it will be performed in accordance with the terms of the framework agreement, without reopening competition proceedings, as long as the agreement sets out all terms concerning the provision of the works, services and supplies concerned and objective conditions for selecting economic operators, who are a party to the framework agreement, to perform them. Since in this case a separate contract is not awarded, it seems that at least here the conclusion of a framework agreement is equivalent to awarding a public contract.

In the context of the subject of this study, special attention needs to be paid to this part of Article 33(2) of Directive 2014/24/EU in which it provides as follows: "[c]ontracts based on a framework agreement may under no circumstances entail substantial modifications to the terms laid down in that framework agreement, in particular in the case referred to in paragraph 3 [a framework agreement concluded with a single economic operator]'.

The reference to paragraph 3 seems to be linked to the fact that contracts based on such agreement are awarded under the conditions laid down solely in that agreement. As a result, contracts could be a simple way of circumventing the provisions of a framework agreement. Consequently, it seems that third paragraph of Article 33(2) is merely a confirmation and emphasis of the application of rules of contract modification laid down in Article 72 to the particular context of framework agreement. ${ }^{111}$ However, Marta Andrecka (now Andhov) rightly points out that in some cases the application of certain provisions of Article 72 to framework agreements may be difficult, if not impossible. This concerns, in particular, provisions regarding a change of contract value, like the first sentence of the second paragraph of Article 72(1) (b), which - similar to Article 72(1)(c)(iii) - limits a possible modification in such a way that an 'increase in price' cannot exceed ' $50 \%$ of the value of the original contract'. Furthermore, Article 72(2) provides that a contract may be modified if the modification value does not exceed the EU thresholds and 10 or 15 per cent of the original contract value for service and supply contracts and for works contracts, respectively. And yet, even though a framework agreement should determine price conditions, this does not mean that the specific price of a given contract will always be specified in the framework agreement. The parties may as well determine only its range (e.g., the minimum price).$^{112}$

110 See 'Explanatory Note - Framework Agreements - Classic Directive', available at: https://ec.europa.eu/docsroom/ documents/15474/attachments/1/translations/en/renditions/pdf, p 2 (accessed on: 14.6.2021). It is worth noting that, according to the Commission, the difference is also manifested by different terminology (contracts and agreements).

111 Arrowsmith (n 6), p 1139.

112 Marta Andrecka (now Andhov) (n 106), p 146. See, however, judgment of the Court of 19 December 2018, Case C-216/17 Autorità Garante della Concorrenza e del Mercato - Antitrust $i$ Coopservice, ECLI:EU:C:2018:1034 in which the Court held that although the contracting authority that is an original party to the framework agreement is subject only to a requirement to use best endeavours with regard to the value and frequency of each of the subsequent contracts to 


\section{CONCLUSIONS}

1.74 Directive 2014/24/EU does not contain a legal definition of a contract, but it does define a 'public contract'. According to Directive 2014/24/EU, a public contract is a contract that must be concluded in writing and for pecuniary interest, where its parties must be one or more economic operator and one or more contracting authority, and which must provide for the execution of works, the supply of products or the provision of services.

1.75 As a rule, under Directive 2014/24/EU, a contract modification will also be a contract per se.

1.76 The elements comprising the definition of 'public contract' do not, by and large, raise any major controversies, and they have been clarified in the CJEU case law. In particular, the notion of 'pecuniary interest' has been the subject of the Court's judgment and opinions of Advocates General.

1.77 The subject matter of a contract is the execution of works, supply of products or the provision of services. Consequently, changes in this scope will constitute modifications in the meaning of Directive 2014/24/EU. The same applies to the replacement of an economic operator. Directive 2014/24/EU states that 'at least' one economic operator must be a party to a contract. This naturally means that more than one economic operator may be a party to a contract, as a consortium. This issue is significant as changes to the composition of the consortium after a contract has been awarded may potentially constitute a contract modification. Subcontractors are not parties to public procurement contracts, but replacing a subcontractor may also be relevant in the context of provisions regarding contract modification. ${ }^{113}$

1.78 The definition of 'public contract' does not make any reference to its term. An analysis of the public procurement directives leads to the conclusion that contracts regulated by Directive 2014/24/EU and Directive 2014/25/EU may be concluded for a fixed or an indefinite term, whereas concession contracts, pursuant to Directive 2014/23/EU, may only be concluded for a fixed term. A change, and in particular an extension of the term of a contract, may mean a substantial modification of a contract.

1.79 For the first time in history, public procurement directives have regulated the issue of contract termination, including in connection with a substantial modification of a contract. The termination of an agreement modifying a contract may therefore be one of the consequences of an impermissible modification of a contract. However, the new provisions at hand raise certain doubts. It is not clear, among other things, whether the contracting authority merely has the right to terminate a contract after circumstances specified in Article 73 of Directive 2014/24/ EU materialise, or is under an obligation to do so.

be awarded, it is nevertheless imperative that that authority state the total quantity which the subsequent contracts may comprise (para 60).

113 For more details see Section C in Chapter 2. 